thorax, two black spots at base of each elytron, and one very large subquadrate spot before tip. Tarsi black, and under side of thorax and abdomen more or less black. Occurs very numerously near Las Cruces, N. Mex., on Larrea mexicana, particularly on flowers. Det. by Liebeck.

Cantharis deserticola Horn.-This is a black meloid, with orange head and thorax. Three specimens from Grant County, N. Mex. (W. J. H.). Det. by Riley.

Cantharis nuttalli Say.-This is a beautiful metallic green species, the elytra with a greenish purple luster. The wing covers are rather tapering apically. One from Grant County, N. Mex. (W. J. H.). Det. by Riley.

Cantharis cyanipennis Say.-This is a purplish blue species, with tapering elytra, somewhat smaller than $C$. nuttalli. One from Grant County, N. Mex. (W. J. H.). Det. by Riley.

Cantharis biguttata Lec.-One specimen collected at Zuni Pueblo, N. Mex., July 29, I892. It is yellowish in color. Det. by Riley.

Cantharis sphaericollis Say.-Two specimens of this beautiful green species were found on San Francisco Mountain, Arizona, July 15, 1892. Western slope, probably about 10,000 feet. Det. by Liebeck.

Eupompha fissiceps Lec.-One from Las Cruces, on mesa toward Organ Mountains, July, r892, (E. C. Holmes). This is a beautiful bluish green metallic species, with head and legs rufous. The elytra are roughened. Det. by Riley.

\title{
A PRELIMINARY LIST OF THE ACRIDIDAE OF NEW ENGLAND.
}

\section{BY ALBERT P. MORSE, WELLESLEY, MASS.}

In the following list I have sought to aid the student beginning the study of this family by providing a catalogue and ready means of indicating, for exchange or other purpose, the species and more noticeable less important forms of locusts found in New England. While several points yet remain to be settled regarding the relations of certain forms and the identity of others, it is believed that the list will be found convenient to use and practically complete.
In order to make it as complete and correct as possible I shall be grateful for information of any errors and desirable or necessary additions. This desire, together with the hope that it will lead to wider interest in and a more thorough knowledge of the group, leads me to publish it at the present time.

The New England representatives of the family Acrididae are distributed in this list among five subfamilies, twentythree genera, forty-five well-defined 
species, witl two additional forms of doubtful specific value, and about ten tolerably distinct forms characterized by unimportant variations in color and structure; some of these last have been and still are occasionally referred to as species. Of this number two are new species recently described and six have not been reported in previous lists, while several names occurring in the literature of the group have been reduced to synonyms or retained in places below specific rank.

I have met in the field in various parts of New England all but two species, and one of these I have taken in an adjoining state, while $I$ have examined representatives of all. Some of them are the most abundant of insects while others are extremely rare, one species, Hesperotettix viridis Thos., not having been reported, so far as I am aware, from the territory east of the Mississippi River until taken by me at Wellesley.

The list is based chiefly upon material personally collected, but also upon an examination of the types of the species described by Mr. Scudder - to whom I am under obligation in many ways-together with other material in his collection, and upon the more important literature on the group. To $\mathrm{Mr}$. Wm. Beutenmüller I am indebted for notes on those species occurring in the vicinity of New York.

A few of the principal synonyms and names less exactly equivalent accompany those of the species and genera in the list and I have added in the index the generic and specific names used in eight of the most important or generally accessible publications (see index) on the New England members of the family, referring to the numbers borne by those groups in the list, thus making it to a considerable degree synonymical and bibliographical, a feature which the novice and possibly others will appreciate. Such notes as it seemed would render the list more convenient to use are also added to it and references to descriptions of certain species not included in the literature cited, as well as to the more useful of those contained therein.

A more extended work containing diagnostic keys and notes on the habits and distribution of the species is contemplated.

In numbering the species and forms I have not attempted to indicate the difference between subspecies, variety, and dimorphic form, but have used a somewhat elastic modification of the decimal method which I trust will be found clear, brief, and in consequence convenient to use in designating these forms in exchanges, e.g., and readily capable of sufficient extension to allow of all necessary additions likely to occur. This method is as follows:each species is indicated by a numeral ; each of its marked forms distinguished by structural characters by a decimal of this; each form distinguished by general coloration by a figure in the hundredths place; and in case of color differences pertaining to special parts by a figure in the thousandths place. 
Its application will be readily understood by examining successively Nos. $33,34, \mathrm{I}$ I, 2 , and 24 .

Additional forms of the numbered species can be readily inserted by continuing the notation, and other species can be added by prefixing a letter to the number of the preceding species.

\section{LIST.}

The principal synonyms are enclosed in parentheses. References to the more useful descriptions are indicated by abbreviations arranged alphabetically (see literature in index).

$$
\begin{aligned}
& \mathrm{C}=\text { Comstock,-Introd. to Entom. } \\
& \mathrm{F}=\text { Fernald,-Orth. N. E. } \\
& \mathrm{H}=\text { Harris, -Ins. Inj. Veg. } \\
& \mathrm{ScI}=\text { Scudder,-Mat. Monog. } \\
& \mathrm{ScII}=\text { " , -in Geol. N. H. } \\
& \mathrm{SmM}=\text { Smith,-Orth. Maine. } \\
& \mathrm{SmC}=\text { ", "- Conn. } \\
& \mathrm{T}=\text { Thomas,-Syn. Acrid. N. A. }
\end{aligned}
$$

The generic names are those in general use; the specific names are for the most part those given in the works of Fernald and Scudder except where recent studies have shown the need of change.

\section{TRYXALINAE.}

\section{Chloealtis (Chrysochraon).}

See notes on the forms of this genus in Psyche, 1894, pp. 13, 14.

I. conspersa Harr. $\mathrm{C}$ 102, $\mathrm{F}_{36} 6, \mathrm{H}$ 184, $\mathrm{SmM}_{145}, \mathrm{SmC}_{375}, \mathrm{~T} 76$.

.oo conspersa Harr., punctate.

.or " abortiva Harr., maculate. $\mathrm{H}$ i84.

2. viridis Scudd., wings short. F $3_{6}^{6}$, $\mathrm{ScI} 455, \mathrm{SmC} 374, \mathrm{~T} 75$.

.00 viridis Scudd., wings short, green. .or viridis Scudd, wings short, brown.
.I viridis punctulata Scudd., wings long. $\mathrm{F}_{36}$, ScI $455, \mathrm{~T} 77$.

.ro viridis punctulata Scudd., wings long, green.

.I I viridis punctulata Scudd., wings long, brown.

\section{Stenobothrus.}

For description of St. olivaceus and critical and diagnostic notes on several forms of this genus see Psyche, 1893, 477-479. St. speciosus Scudd. is erroneously reported from Mass. and Conn. in Gerstaecker, Archiv. f. Nat., xxix, ii, 358 .

3. curtipennis Harr. $\mathrm{C}$ IO2, $\mathrm{F} 37, \mathrm{H}$ I $84, \mathrm{SmM}_{\text {I47 }}, \mathrm{T}_{9 \mathrm{I}}$.

.o curtipennis Harr., wings short.

.I " $\quad$ longipennis Scudd., wings

long. ScI $457, \mathrm{SmM} 447$.

4. aequalis Scudd. (maculipennis). C IO2, F 37, ScI 459, T 89 .

.00 aequalis Scudd., green.

.or “" bilineatus Scudd., brown. $\mathrm{ScI} 460, \mathrm{~T} 90$.

5. pelidnus Burm. (propinquans). ScI 46r, T 90.

$\mathrm{Mr}$. Scudder informs me that from an examination of Burmeister's type St. propinquans Scudd. is a synonym. From an examination of the types of St. propinquans and a small number of other N. E. specimens I suspect that they must be considered as longwinged individuals of $S t$. aequalis Scudd. As this would involve a considerable shifting of names it seems best to give each a place until additional evidence accumulates. The type of Burmeister came from Penn'a. I have seen specimens from the west, referred to this name by good authorities, which belonged to a distinct species, not found, so far as I am aware, in New England. 
6. maculipennis Scudd. ScI 458, T 87. $\begin{array}{llll}.00 & \text { ، } & \text { ، } & \text {, green. } \\ \text { OI } & \text { ، }\end{array}$

7. olivaceus Morse. See note under genus. .00 " " " , green.

or " " " , brown.

3. Stethophyma (Arcyptera).

8. lineata Scudd. $\mathrm{F}_{3} 8, \mathrm{ScI}_{462}, 463, \mathrm{~T}_{98}$

9. gracilis Scudd. ScI $463, \mathrm{~T} 99$.

Io. platyptera Scudd. ScI $463, \mathrm{~T} 99$.

\section{OEDIPODINAE.}

4. Chortophaga (Tragocephala).

II. viridifasciata DeG. C ro4, F 40, H I $82, \mathrm{~T}$ 103.

.oo viridifasciata virginiana Fab., green.

.or " infuscata Harr., brown. $\mathrm{H}$ i8r, $\mathrm{T}$ 102.

. or I viridifasciata infuscata radiata Harr., wing veins black. $\mathrm{H}_{1} 83$.

\section{Encoptolophus (Oedipoda).}

12. sordidus Burm. (nebulosa) $\mathrm{C}$ 103, $\mathrm{F}$ 4I, H I8I, T I I6.

6. Arphia (Tomonotus, Oedipoda).

13. xanthoptera Burm. F 39, ScI 469-470, $\mathrm{SmC} 372$, T 105 .

I4. sulphurea Fab. F 39, ScI 470, SmC $372, \mathrm{~T}$ 105.

7. Camnula (Oedipoda).

r5. pellucida Scudd. F $4 \mathrm{I}, \mathrm{ScI}_{472}, \mathrm{~T}_{137}$.

8. Hippiscus (Oedipoda).

16. rugosus Scudd. $\mathrm{F}_{42}, \mathrm{ScI} 469, \mathrm{~T} \mathrm{I}_{32}$.

17. tuberculatus Pal. de B. (phoenicoptera, corallina). $\mathrm{F}_{42}, \mathrm{H}$ I76, SmC $37 \mathrm{I}, \mathrm{T}$ I35.

9. Dissosteira (Oedipoda).

18. carolina Linn. C 104, F 43, H I76, $\mathrm{SmC}_{37 \mathrm{I}}, \mathrm{T} \mathrm{II}_{17}$.
Io. Spharagemon (Oedipoda, Dissosteira).

For an extended treatment of the N. E. species of this genus see Proc. Bost. soc. nat. hist., v.xxvi, p. 220-240.

19. aequale Say. (F I43, $\mathrm{H}$ I78, $\mathrm{T}$ II4)? .or “ scudderi Morse. See note under genus.

bolli Scudd. (balteatum, aequale). $\mathrm{C}$ 104, $\mathrm{F}_{43}$.

2I. saxatile Morse. See note under genus.

I I. Scirtettica (Dissosteira, Oedipoda).

22. marmorata Harr. F 44, H I79, $\mathrm{T}$ III.

I2. Circotettix (Oedipoda).

23. verruculatus Kirby (latipennis). F $45, \mathrm{H}_{179}, \mathrm{ScI} 47 \mathrm{I}, \mathrm{T}$ I 5 .

13. Psinidia (Oedipoda, Locusta).

24. fenestralis Serv. F 44, $\mathrm{H}_{180}, \mathrm{SmC}$ $373, \mathrm{~T}$ I 18, II9.

.000 fenestralis Serv., wings red.

.OOI " eucerata Harr., wings yellow. $\mathrm{H}$ I80, T I I9.

14. Trimerotropis (Oedipoda, Locusta).

25. maritima Harr. $\mathrm{F}_{45}, \mathrm{H} \mathrm{I}_{7} 8, \mathrm{SmC}$ $373, \mathrm{~T}$ I24.

\section{ACRIDINAE.}

\section{I5. Schistocerca (Acridium).}

26. alutacea Harr. $\mathrm{C}$ 106, F 31, H I73, $\mathrm{SmC} 370$, T I7 .

27. rubiginosa Harr. C I06, F 3 I, ScI $467, \mathrm{SmC}_{370} \mathrm{~T}$ г7o.

16. Paroxya.

28. atlantica Scudd. F 34 .

.OI " " , melanistic. 
I7. Hesperotettix (Ommatolampis).

29. viridis Thos. $\mathrm{T} \mathrm{I}_{5} 6$.

r8. Melanoplus (Caloptenus, Pezotettix).

30. bivittatus Say (flavovittatum). .0OI " femoratus Burm. C I Io, F

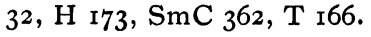

Mr. W. S. Blatchley of Indiana finds these two forms paired and considers them to belong to one species. $M$. femoratus, the red-legged form, is alone found in New England, but of $M$. minor specimens with red and with glaucous hind tibiae are about equally plentiful.

3I. punctulatus Uhl. (griseus). F 32, ScI $46_{5}, \mathrm{~T}$ I63, I65.

32. femur-rubrum DeG. C I Iо, $\mathrm{F}_{33}, \mathrm{H}$ I74, $\mathrm{SmC} 362, \mathrm{~T}$ r63.

33. atlantis Riley. C I I0, F 33 .

34. junius Dodge.

. 6 " " " wings short.

. $\mathrm{I}$ " " " " long.

For description see Canadian En. tomologist, viii, p. 9, 1876 .

35. minor Scudd.

.000 " " " 6 , hind tibiae glaucous. .OOI " " " " " 6 r

For description see Proc. Boston soc. nat. hist. xvii, 478, (1875), or Scudder's Century of Orthoptera, p. 22, (no. 30).

36. collinus Scudd. F 32 .

\section{Pezottetix.}

Pezotettix and Melanoplus are here used merely in the sense of indicating the shorter-and longer-winged series of species.

37. borealis Fieb. (borealis Scudd., rectus, septentrionalis). $\mathrm{F} 32,33, \mathrm{ScI}$ 464, SmM I 49, T I 53, 222, 227.
I have elsewhere (Psyche, I894, p. 53) stated my belief that $\mathrm{Mel}$. rectus Scudd. = Pez. borealis Scudd. and $\mathrm{Mr}$. Scudder had previously stated the probability that borealis $=$ septentrionalis Sauss. On calling his attention to the description by Brunner von Wattenwyl (Verh. zool. bot. gesel. Wien $I 86 \mathrm{r}, 223$ ) of a specimen from Labrador referred to Cal. borealis Fieb. he kindly looked into the matter with me and expressed the opinion that the synonymy should probably be as follows: Caloptenus borealis Fieb., 1853 (orig. descr. in Lotos III, p. I20, I853, Labrador) $=$ Cal.borealis Fieb. (auct. Brunner), 1861, = Pez. septentrionalis Sauss., I861, = Pez. borealis Scudd., I862, $=M e l$. rectus Scudd., I878. Brunner's description fits better than that of Fieber.

38. scudderi Uhl. $\mathrm{C}_{\text {ro7 }}, \mathrm{SmC}_{370}, \mathrm{~T}_{152}$. 39. manca Smith. F 30, Sm M I 49, T 149. 40. glacialis Scudd. $\mathrm{C}_{\text {I07, }} \mathrm{F}_{29}$, T I48.

\section{OPOMALINAE.}

20. Opomala.

4I. brachyptera Scudd. F 35, ScI 454, T 63.

.o brachyptera Scudd., wings short.

. I “ " , " " long.

TETTIGINAE.

See remarks on New England species in Psyche, I894, pp. 53, 54.

2I. Tettix (Tetrix).

42. granulatus Kirby. $\mathrm{F}_{46}, \mathrm{ScI} 474, \mathrm{~T}$ I82.

43. ornatus Say. $\mathrm{F}_{46}, \mathrm{ScI}_{474}, \mathrm{~T}$ I83. 
.I ornatus triangularis Scudd., wings and pronotum abbreviated. F 47, $\mathrm{ScI} 475, \mathrm{~T}$ I85.

44 cucullatus Burm. F 47, ScI 474,475 , $\mathrm{T}$ i 85 .

\section{Batrachidea.}

45. cristata Harr. F 48, ScI 478, SmC $377, \mathrm{~T}$ 190.

.o cristata Harr.

.I " carinata Scudd., wings and pronotum long. F 49, ScI 479, T I90.

These forms have been placed in Tettix by some recent authors.

\section{Tettigidea (Tetrix).}

46. lateralis Say. F 48, $\mathrm{H} \mathrm{I87,} \mathrm{ScI} 477$, $\mathrm{T}$ i87.

47. polymorpha Burm. $\mathrm{F}_{48}, \mathrm{H}$ i $87, \mathrm{ScI}$ $477, \mathrm{SmC} 377, \mathrm{~T}$ ז88.

Additional species especially to be looked for are Schistocerca americana and Spharagemon oculatum. These have been taken on Staten Id. Mr. Beutenmüller suggests also Acridium obscurum and Hippiscus discoideus which have been found in New Jersey.

\section{INDEX.}

In addition to the names used in the list, those occurring in the eight most important or generally accessible works on the New England Acrididae are included. These works are the following:-

$\mathrm{C}=$ Comstock, J. H. - Introduction to Entomology (pp. 97-II2). Pub. by author, Ithaca, N. Y., 1888.

$\mathbf{F}=$ Fernald, C. H. - The Orthoptera of New England, pp. 6I; same, in 25th Report Mass. Agric. College (pp. 85-
145), Jan., r888; same, in Report Sec. Board Agric. Mass., I887, (pp. 42I48I). The pagination of the separate is used.

$\mathrm{H}=$ Harris, T. W. - A Treatise on some of the Insects Injurious to Vegetation, $3^{\text {rd }}$ ed., 1862 (pp. 165-191). First edition pub. I841.

$\mathrm{ScI}=$ Scudder, S. H. - Materials for a Monograph of the North American Orthoptera, including a Catalogue of the known New England Species,- in Boston Journ. Nat. Hist., vol. vii, no. iii, I862 (pp. 409-480).

$\mathrm{ScII}=i b i d .-$ The Distribution of Insects in New Hampshire, in Hitchcock's Geol. N. H., vol. i, 1874 (pp. 370-379).

$\mathrm{SmM}=$ Smith, S. I. - On the Orthoptera of the State of Maine, in Proc. Portland Soc. Nat. Hist., I868 (pp. I43-15I).

$\mathrm{SmC}=i b i d .-$ Report of the Entomologist to the Conn. Board of Agric. for I872, in Annual Rep't Sec. Agric. Conn. for I 872 (pp. 345-383).

$\mathrm{T}=$ Thomas, Cyrus. - Synopsis of the Acrididae of North America. Rep't U.S. Geol. Surv. Terr., Hayden, vol. v, pt. i, I873,-pp. x, 262.

So much of the bibliography and synonymy is given in this literature (especially in F, ScI, and $T$ ) that it seemed unwise to encumber this list with them. The principal synonyms are inserted in the list; to find additional ones note the number of the species in the list and look for it among the right-hand numbers in the index.

Generic names begin with a capital, specific with a lower case letter.

Names are numbered according to the list. Those numbered at the left will be found in the list; those numbered at the right have been used in an erroneous or more or less synonymical sense, and the numbers are those borne in the list by the species to which reference is made. 

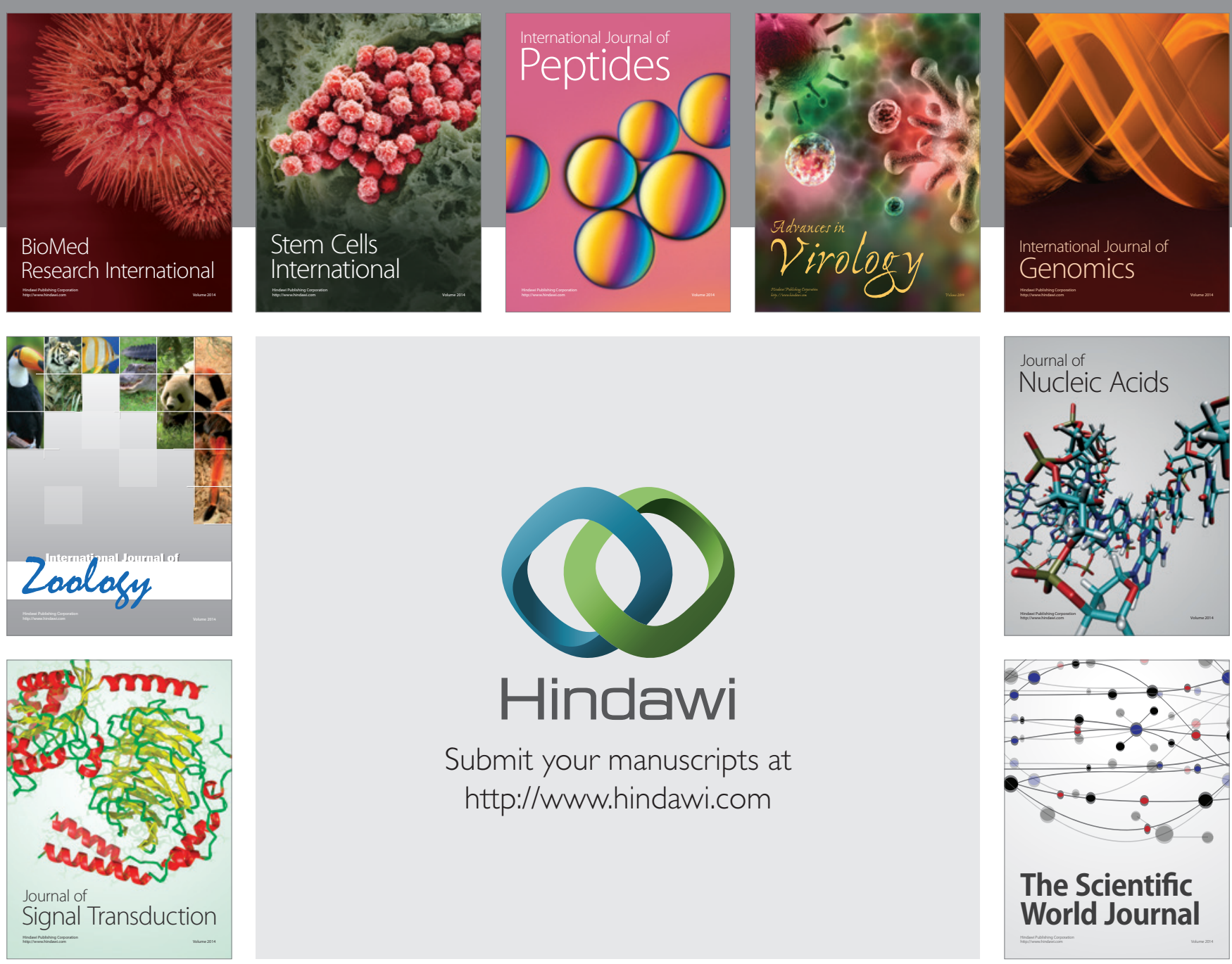

Submit your manuscripts at

http://www.hindawi.com
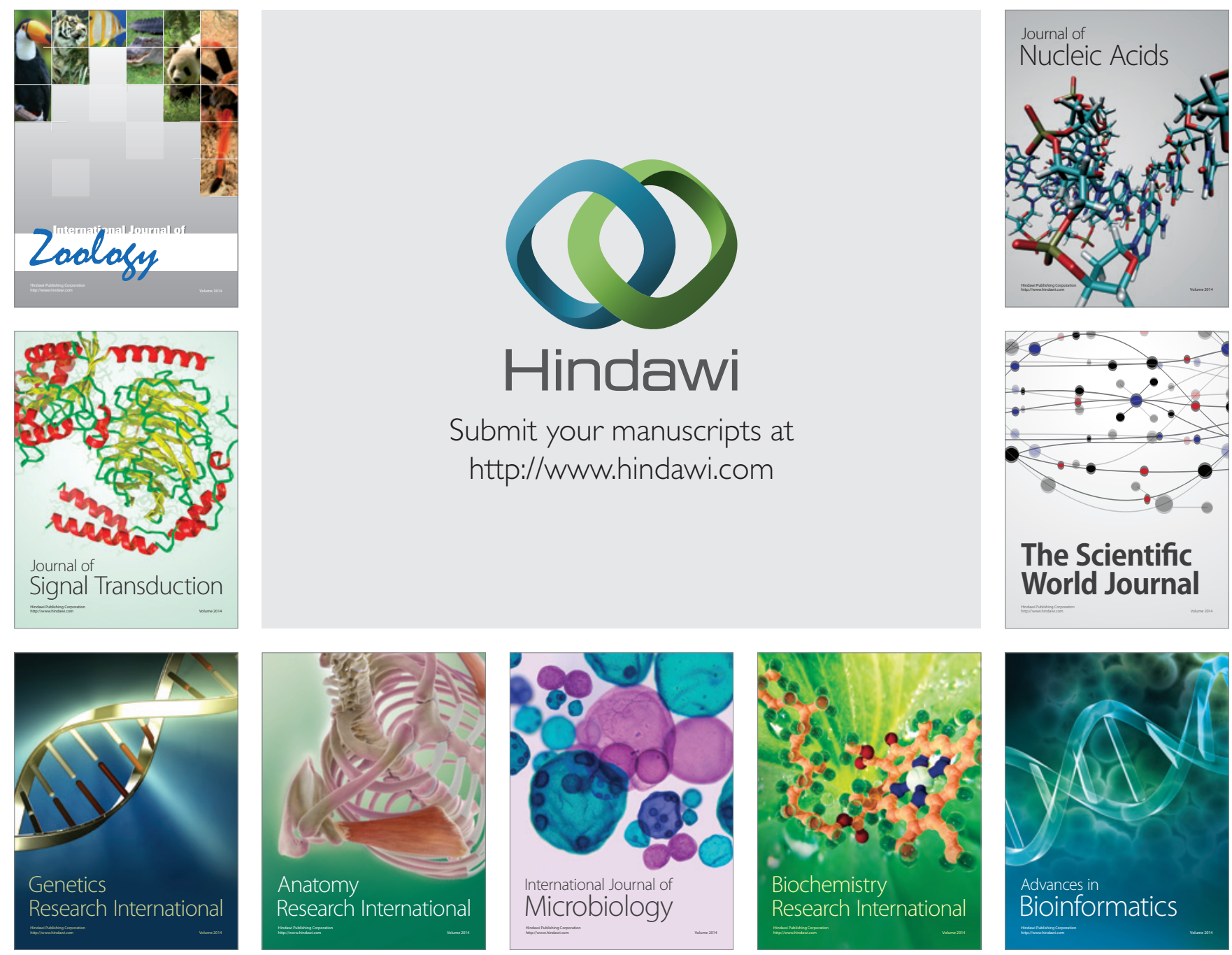

The Scientific World Journal
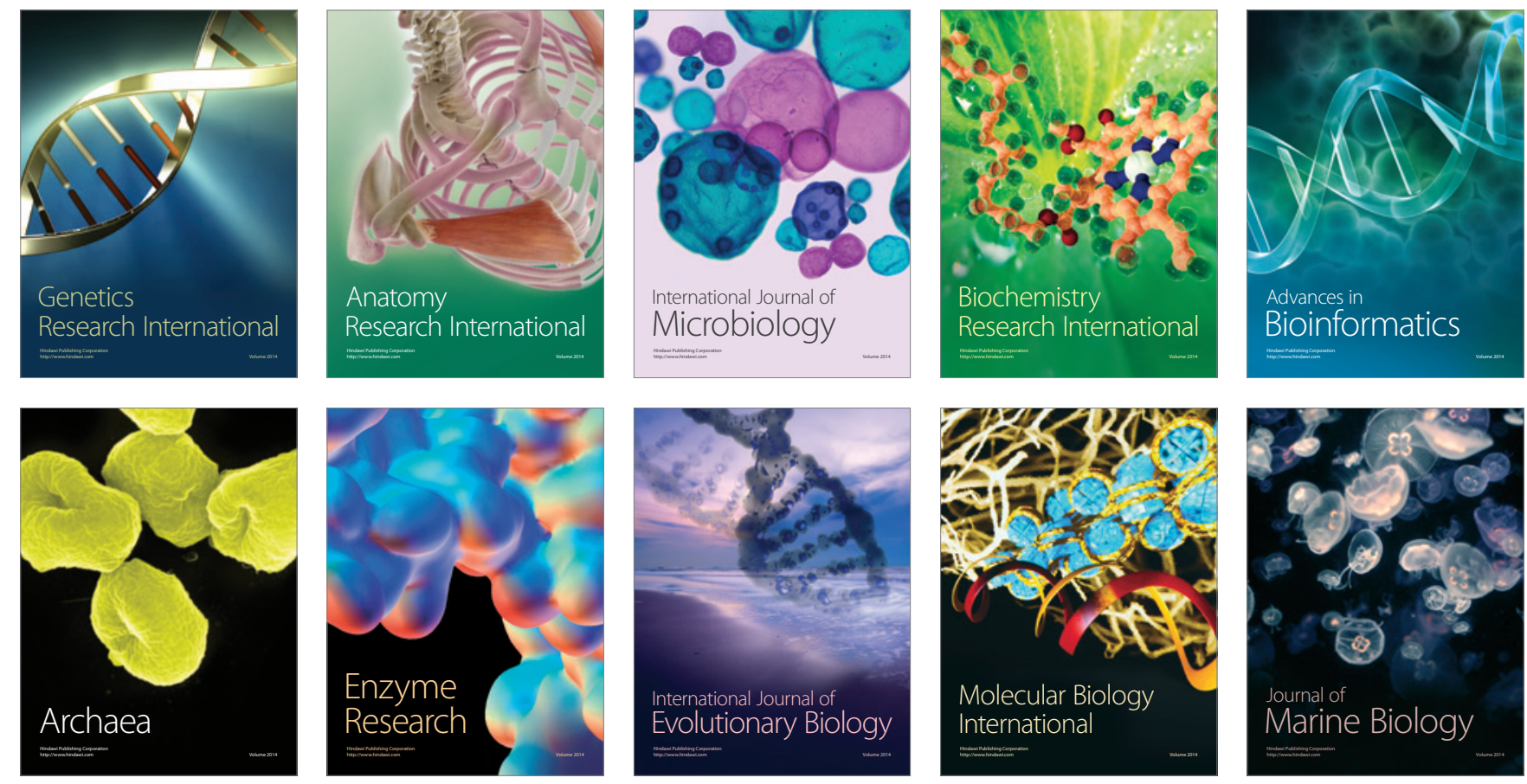